\title{
Proximate and Amino Acid Analyses of the Rhizome of Nymphaea lotus (Water Lily)
}

\author{
Amagbor Stella Chinelo ${ }^{1}$, Umar Kabiru Jega ${ }^{2}$ \\ ${ }^{1}$ Department of Biological and Chemical Sciences, Michael and Cecilia Ibru University, Agbarha-Utor, Nigeria \\ ${ }^{2}$ Department of Pure and Industrial Chemistry, Federal University, Birnin Kebbi, Nigeria
}

Email address:

stellachineloamagbor@gmail.com(A. S. Chinelo)

\section{To cite this article:}

Amagbor Stella Chinelo, Umar Kabiru Jega. Proximate and Amino Acid Analyses of the Rhizome of Nymphaea lotus (Water Lily). Modern Chemistry. Vol. 7, No. 3, 2019, pp. 54-57. doi: 10.11648/j.mc.20190703.12

Received: August 16, 2019; Accepted: September 16, 2019; Published: September 26, 2019

\begin{abstract}
The proximate composition and the amino acid profile analyses of the rhizome of Nymphaea lotus (water lily) were carried out based on standard methods reported by the association of official Analytical Chemists (AOAC). The results of the proximate analysis showed that Nymphaea lotus rhizome had moisture content of 48.83 \pm 3.22 ; crude protein 4.23 \pm 0.06 ; crude fibre 5.00 \pm 1.50 ; ash content $4.67 \pm 0.17$; high available carbohydrate $35.44 \pm 0.01$ and energy value $742.10 \mathrm{~kJ} / 100 \mathrm{~g}$. The crude lipid content was low $1.83 \pm 0.60$. The study detected seventeen different amino acids. The amino acid content in $\mathrm{g} / 100 \mathrm{~g}$ protein content was: lysine $=3.11$, histidine $=1.82$, arginine $=4.25$, aspartic acid $=7.60$, threonine $=2.19$, serine $=3.02$, glutamic acid $=9.68$, proline $=2.34$, glycine $=3.06$, alanine $=3.40$, cycteine $=0.73$, valine $=3.37$, methionine $=1.09$, isoleucine $=2.35$, leucine $=8.24$, tyrosine $=2.25$ and phenylalnine $=3.72$. The studied revealed that glutamic acid, aromatic acids, leucine and aspartic acid were the predominant amino acids. All essential amino acids were found to be higher than WHO/FAO/UNU requirement pattern for adults while leucine was found to be higher than the requirement pattern for preschool children. Lysine however was found to be the most limiting amino acid for preschool children. The presence of these compounds of nutritive value, as well as high energy value suggests that Nymphaea lotus rhizome could serve as a food supplement for livestock and humans.
\end{abstract}

Keywords: Proximate Analysis, Amino Acid Profile, Nymphaea lotus Rhizome

\section{Introduction}

Currently, the world, especially developing nations is facing the problem of malnutrition. The major causes of this malnutrition are war and bad economic policies. Conventional legumes and some dicotyledonous seeds, which have been proven to be economically favourable alternative sources of proteins and energy as against animal proteins in developing countries, have played significant role in the management of these problems so far [1]. However, these are still insufficient for complete fulfillment of food and energy requirements of the fast growing population. In most parts of Nigeria, starch based food are the main staple food which supply both energy and protein. Thus, protein deficiency prevails among the populace as recognized by Food and Agricultural Organization, FAO [4]. Recent reports have revealed that quite a large number of indigenous plant species are high in nutrient value [2]. However, many of such plants have been identified but lack data on their chemical compositions [3]. Hence, there is need for exploration of non-conventional sources of nutrients supplements.

One of such non-conventional sources of nutrient is the water lily (family, nymphaeaceae). Water lilies are aquatic plants growing perennially from a sunken stem buried in the mud, where the rootlets of the plant put away for anchor with the asexual parts emerging above the water surface. It is one of the foremost aquatic macrophytes that have been identified in the Nigerian fresh water bodies [5]. The impact of some macrophytes on water bodies, have been highlighted by many authors [6-9]. However, there is dearth of information on water lily despite its presence on many fresh water bodies in Nigeria [10]. It has however been observed that people of the north eastern part of Nigeria eat and market the seeds of water lily [11]. In the light of this fact, it is clear that water lily may be a sole contributor to resolve the malnutrition problems in developing countries. The nutritional 
composition of the bulb of Nymphaea lotus has been reported [9]. However, nothing has been done on the rhizome of this plant. It is therefore the aim of this work to study the proximate and amino acid profile analyses of the rhizome of Nymhpaea lotus.

\section{Materials and Methods}

\subsection{Sample Collection and Preparation}

The Nymphaea lotus rhizomes were collected from Dan Gurbi Lake in Randa village, Tureta Local Government Area of Sokoto state, Nigeria. The sample was oven dried at $105^{\circ} \mathrm{C}$, cooled in a dessicator and finely ground. The dried sample was used for the analyses, except for moisture content determination in which fresh sample was used.

\subsection{Proximate Analysis}

The proximate analysis (moisture content, ash content, crude protein, crude fibre, crude lipid, total carbohydrate and energy value) of Nymphaea lotus rhizome were determined using standard methods [12].

\subsection{Amino Acid Profile}

Amino acid determination was carried out using ionexchange chromatography with Technicon Sequential Multisample Amino Acid Analyser, TSM (Technicon Instruments Corporation, Dublin, Ireland) at Postgraduate laboratory, Zoology unit, University of Jos, Nigeria as outline in [13]. $2 \mathrm{~g}$ sample was defatted with petroleum ether using Soxhlet extraction methods. The defatted sample was redried and milled into fine powder using porcelain pestle and mortar. $30 \mathrm{mg}$ sample in duplicate were weighed into a glass ampoules to which $5 \mathrm{~cm}^{3} 6 \mathrm{M} \mathrm{HCl}$ and $5 \mu$ moles norleucine were added. The ampoules were evacuated by passing nitrogen gas (to remove oxygen so as to avoid possible oxidation of some amino acids during hydrolysis), sealed with Bunsen burner flame and hydrolyzed in an oven at $110^{\circ} \mathrm{C}$ for 24 hours. The ampoules were cooled, broken at the tip and the contents filtered. The filtrates were evaporated to dryness at $40^{\circ} \mathrm{C}$ under vacuum in a rotary evaporator. The residues were dissolved to $5 \mu \mathrm{L}$ (for acid and neutral amino acids) or $10 \mu \mathrm{L}$ (for basic amino acids) with acetate buffer, pH 2.2 and the solutions were dispensed into the cartridge of TMS. The chromatograms (amino acid peaks) obtained from automatic pen recorder corresponds to the quantity of each amino acid present. Quantification was performed by comparing the peak area of each amino acid in the sample to the area of the corresponding amino acid standard of the protein hydrolysate.

\section{Results}

The results of the analysis, involved proximate analysis and amino acid profile of the rhizome of Nymphaea lotus and they are shown in the tables 1,2 and 3 below.

\section{Discussion}

\subsection{Proximate Analysis}

The results of the proximate analysis of the rhizome of Nymphaea lotus were compared with that reported for the bulb of the same plant [9]. This is summarized in table 1.

Table 1. Result of proximate analysis of Nymphaea lotus rhizome compared to literature values.

\begin{tabular}{lll}
\hline Parameter & $\begin{array}{l}\text { \% concentration } \\
\text { (mean } \pm \text { SD) }\end{array}$ & $\begin{array}{l}\text { \% concentration for } \\
\text { bulbs from literature [9] }\end{array}$ \\
\hline Moisture content & $48.83 \pm 3.22$ & $9.72 \pm 0.000$ \\
Ash content & $4.67 \pm 0.17$ & $8.34 \pm 0.007$ \\
Crude lipid & $1.83 \pm 0.60$ & $5.07 \pm 0.014$ \\
Crude protein & $4.23 \pm 0.06$ & $21.66 \pm 0.014$ \\
Crude fibre & $5.00 \pm 1.50$ & $13.30 \pm 0.021$ \\
Available carbohydrate & $35.44 \pm 0.01$ & $41.92 \pm 0.056$ \\
\hline
\end{tabular}

From the table, the moisture content for this research work is high, $(48.83 \pm 3.22)$ and is also higher than the value reported for the bulb of $N$. lotus $(9.72 \pm 0.000)$ in the literature which is also similar to the result obtained for the leaf sample $(7.50 \pm 0.50)$, root sample $(9.00 \pm 0.48)$ and seed sample $(6.00 \pm 0.45)$ [14]. The high moisture content of the rhizome implies that it is likely to have a short storage capability [15]. The ash content showed a lower value $(4.67 \pm 0.17)$ compared to the literature as shown in the table. The value for the ash content is also low compared to that of the leaf sample $(12.67 \pm 1.26)$ and the root sample (26.67 \pm 1.89$)$. It is however higher than the value reported for the seed sample $(2.67 \pm 0.29)$ [14]. The ash content shows a reflection of the mineral contents preserved in the rhizome. Minerals are essential for the proper functioning of tissues and act as second messengers in some biochemical mechanisms [16]. The rhizome from this research, as shown in table 1 has very low crude lipid $(1.83 \pm 0.60)$ while the reported literature for the bulb showed higher lipid content (5.07 \pm 0.014$)$. The lipid content of most parts Nymphaea lotus is low as shown in literature, where the leaf and root samples gave values within the range for the rhizome (2.18 and 2.00 respectively). However, the seed sample showed higher crude lipid similar to the bulb in the table above $(9.33 \pm 0.29)$ [14]. The rhizome, been a low lipid containing food can thus be recommended as part of weight reducing diet, since low fat food reduces the level of cholesterol and obesity [17]. The crude protein was $4.23 \pm 0.06$. This value is higher than that reported for the root and seed samples (1.02 and 1.04 respectively) [14]. The presence of crude protein in the rhizome, suggests that it can serve as a protein supplement to contribute to the daily protein needed by the body. However, the value is less than that reported for the bulb $(21.66 \pm 0.014)$ as shown in table 1 . The percentage crude fibre obtained in this work was $5.00 \pm 1.50$. This is low compared to the bulb $(13.30 \pm 0.021)$, and the root sample $(24.33 \pm 0.58)$ [14]. The value however, is similar to that reported for the seed sample $(5.50 \pm 0.50)$ [14]. The crude fibre content implies that the $N$. lotus rhizome could serve as a source of dietary fibre and can be employed in the treatment of diabetes, obesity and 
gastrointestinal tract diseases [18]. The available carbohydrate content was very high $(35.44 \pm 0.01)$, even though less than that reported for the bulb $(41.92 \pm 0.056)$. The value is also less than that reported for the root sample (61.31 \pm 1.86$)$ [14]. This value of available carbohydrate, suggests that $N$. lotus rhizome is a good source of carbohydrate which is essential for energy in livestock and man.

\subsection{Amino Acid Profile}

Table 2 shows the result for the amino acid profile of $N$. lotus rhizome.

Table 2. Results for the Amino Acid Profile of N. lotus rhizome.

\begin{tabular}{ll}
\hline Amino Acid & Concentration $(\mathbf{g} / \mathbf{1 0 0 g}$ protein) \\
\hline Lysine & 3.11 \\
Histidine & 1.82 \\
Arginine & 4.25 \\
Aspartic acid & 7.60 \\
Threonine & 2.19 \\
Serine & 3.02 \\
Glutamic acid & 9.68 \\
Proline & 2.34 \\
Glycine & 3.06 \\
Alanine & 3.40 \\
Cysteine & 0.73 \\
Valine & 3.37 \\
Methionine & 1.09 \\
Isoleucine & 2.35 \\
\hline
\end{tabular}

\begin{tabular}{ll}
\hline Amino Acid & Concentration (g/100g protein) \\
\hline Leucine & 8.24 \\
Tyrosine & 2.25 \\
Phenylalanine & 3.72 \\
\hline
\end{tabular}

The data are mean value of duplicate results.

The result indicated that non-essential amino acids (alanine, arginine, aspartic acid, glutamic acid, glycine, histidine, proline and serine) were higher in concentration (56.53\%) compared to the essential amino acids (isoleucine, leucine, lysine, methionine, cysteine, phenylalanine, tyrosine, threonine and valine) which constitute $43.48 \%$ of the total amino acids analyzed. Among the essential amino acids, leucine and aromatic (phenylalanine and tyrosine) are the predominant acids, while glutamic and aspartic acids were found to be the major non-essential amino acids in Nymphaea lotus rhizome.

To evaluate the nutritional quality of the rhizome, the percentages of the essential amino acids in the sample were compared with those of reference standard amino acid profile by WHO/FAO/UNU [19] and the result (Table 3) indicates that all the essential amino acids exceeded the reference value for adults, while isoleucine, lysine, sulphur-containing amino acids (methionine and cysteine), total aromatic essential amino acids (phenylalanine and tyrosine), threonine and valine were below the standard requirement for preschool children.

Table 3. Results of the amino acid score for Nymphaea lotus rhizome.

\begin{tabular}{|c|c|c|c|c|c|}
\hline \multirow{2}{*}{ EAA } & \multirow{2}{*}{$\begin{array}{l}\text { Concentration }(\mathrm{g} / 100 \mathrm{~g} \\
\text { protein) }\end{array}$} & \multicolumn{2}{|c|}{ WHO Ideal protein } & \multicolumn{2}{|c|}{$[(\%$ Amino acid $) /$ ideal $] \times 100$} \\
\hline & & $\mathbf{A}$ & B & Children & Adult \\
\hline Isoleucine & 2.35 & 2.8 & 1.3 & 84 & 181 \\
\hline Leucine & 8.24 & 6.6 & 1.9 & 125 & 434 \\
\hline Lysine & 3.11 & 5.8 & 1.6 & 54 & 194 \\
\hline Total sulphur EAAs & 1.82 & 2.5 & 1.7 & 73 & 107 \\
\hline Total aromatic EAAs & 5.97 & 6.3 & 1.9 & 95 & 314 \\
\hline Threonine & 2.19 & 3.4 & 0.9 & 64 & 243 \\
\hline Valine & 3.37 & 3.5 & 1.3 & 96 & 259 \\
\hline Histidine* & 1.82 & 1.9 & 1.6 & 96 & 114 \\
\hline Total EAAs & 27.05 & & & & \\
\hline Total non-EAAs & 35.17 & & & & \\
\hline Total amino acids & 62.22 & & & & \\
\hline$\%$ EAAs in total amino acids & 43.48 & & & & \\
\hline$\%$ non-EAAs in total amino acids & 56.53 & & & & \\
\hline
\end{tabular}

*essential for children $\mathrm{A}=\mathrm{WHO} / \mathrm{FAO} / \mathrm{UNU}$ ideal protein for preschool children aged $2-5$ years. $\mathrm{B}=\mathrm{WHO} / \mathrm{FAO} / \mathrm{UNU}$ ideal protein for adult. EAAs $=$ Essential amino acids.

However, for preschool children, lysine is the most limiting essential amino acid and the second is threonine followed by the sulphur containing essential amino acids. This implies that the rhizome will be more suitable for adults than children.

\section{Conclusion}

This research work showed the proximate analysis and amino acid profile of the rhizome of Nymphaea lotus. It therefore showed the biochemical compositions such as carbohydrates, crude protein, crude lipid, crude fibre and amino acids. From the result of this study, it has been shown that Nymphaea lotus rhizome contains relatively good amounts of nutrients. The low crude lipid imply that this rhizome can serve as a good food supplement for the treatment of obesity and the amino acid profile imply that the rhizome is suitable for adults protein supplement. All these suggest that Nymphaea lotus rhizome can actually serve as a non-conventional food supplement to help combat the problem of malnutrition amongst humans and livestock. People living around areas where this Nymphaea lotus rhizome is found, may look for processing methods to help integrate this into their food for both humans and livestock. 
Furthermore, the nutrient information would enhance efforts to promote wide use of plants because of their nutritional benefits and medicinal properties.

\section{Acknowledgements}

The authors of this research work wish to acknowledge the assistance of the central science laboratory and the technologists of the Agricultural Science laboratory, Usmanu Dan fodiyo University Sokoto, where this work was conducted.

\section{References}

[1] Muhammad, A., Dangoggo, S. M., Tsafe, A. I., Itodo A. U. and Atiku, F. A. (2011). Proximate, Mineral and Antinutritional Composition of Gardenia aqualla Pulp. Pakistan Journal of Nutrition, 10 (6): 577-581.

[2] Lala, S. and Tsakins, J. (2003). Characterization of Moringa oleifera seed oil variety Periyakulam-1. Journal of Food Composition and Analysis, 15: 65-77.

[3] Lohdip, A. M. and Jikmyan, M. S. (2019). Proximate and Amino acid Analyses of the Stem of Sesamum indicum I. (Black Seed specie) pedaliaceae. J. Chem. Soc. Nigeria. 44 (1): 053-058.

[4] Hassan, L. G. and Umar, K. J. (2006). Nutritional Value of Balsam Apple (Momordic balsamina L.) leaves. Pakistan Journal of Nutrition, 5: 522-529.

[5] Obot, E. A. and Ayeni, J. S. O. (1987). A Handbook of Common Aquatic Plants of the Kainji Lake Basin. National Institute for Freshwater Fisheries Research. Saolog Printing Productions, New Bussa.

[6] Obot, E. A. (1984). Studies in the productivity of Echinocloa stagnina (Retz) P. Beuv in the Kainji Lake Basin of Northern Nigeria. Ph.D. Thesis, University of Ife, Nigeria.

[7] Mbagwu, I. G. and Adeniji, H. A. (1988). The Nutritional Content of Duckweed (Lemna pausicostata Hegelm) in the Kainji lake area, Nigeria. Aquatic Botany, 29: 357-366.

[8] Ogunlade, Y. (1996). The Chemistry of Water Hyacinth in Nigerian Waterways. Government Printing Press, Akure Ondo State, Nigeria. Pp 45-47.
[9] Ezeonu, C. S., Arowora K. A., Imo, C. and Ambikya, A. S. (2017). Chemical composition of Water Lily (Nymphaea lotus) Bulbs. American Journal of Food Science and Nutrtion. $4(2): 7-12$.

[10] Mohammed, H. A., Awodoyin, R. O., Daddy, F. and Adesina, G. O. (2008). Ethnobotany of waterlily (Nymphaea lotus Linn.) among the riparian communities in Nigeria: A case study of Kainji Lake Basin. Journal of Environmental Biology, 5: 52-55.

[11] Mohammed, H. A., Uka, U. N. and Yauri, Y. A. B. (2013). Evaluation of Nutritional Composition of Waterlily (Nymphaea lotus Linn.) from Tatabu Food plain, North central, Nigeria. Journal of Fisheries and Aquatic Science, 8: 261-264.

[12] AOAC (Association of Official Analytical Chemist), (2006). Official Method of Analysis of the AOAC. (Washington D. C., AOAC) $18^{\text {th }}$ Edition.

[13] Adeyeye, E. I. and Afolabi, E. O. (2004). Amino acid Composition of three different types of Land Snails consumed in Nigeria. Food Chemistry, 85: 535-539.

[14] Wasagu, R. S. U., Lawal, M., Galadima, L. G., \& Aliero, A. A. (2014). Nutritional composition, anti-nutritional factors and element analysis of Nymphaea lotus (water lily). Bayaro Journal of Pure \& Applied Sciences, 8 (1): 1-5.

[15] Dashak, D. A. and Fali, C. N. (1993). Chemical Composition of four varieties of Bnniseed. FOOD Chemistry. 47: 253-255.

[16] Anita, B. S., Akpan, E. J., Okon, P. A. and Umoren, I. U. (2006). Nutritive and Antinutritive Evaluation of Sweet Potatoes (Ipomea batatas) Leaves. Pakistan Journal of Nutrition, 5: 166-168.

[17] Gordon, M. N. and Kessel, M. (2002). Perspective in Nutrition. 5th edition. McGraw Hill Company, New York. Pp 257-281.

[18] Agostoni, C., Carratu, B., Boniglia, C. and Sanzini, E. (2001). Free Amino Acid content in standard infant formulas: comparison with human milk. Journal of American College of Nutrition, 19: 434-438.

[19] WHO/FAO/UNU. (1985). Report: Energy and protein requirements: WHO technical report series. Geneva. No. 724, pp. 220 . 